\title{
Animal Models in Q Fever: Pathological Responses of Inbred Mice to Phase I Coxiella burnetii
}

\author{
By GEORGE H. SCOTT, ${ }^{*}$ JIM C. WILLIAMS ${ }^{1,2}$ AND \\ EDWARD H. STEPHENSON ${ }^{1}$ \\ ${ }^{1}$ US Army Medical Research Institute of Infectious Diseases, Airborne Diseases Division, \\ Rickettsial Diseases Laboratory, Fort Detrick, Frederick, MD 21701-5011, USA \\ ${ }^{2}$ National Institutes of Health, National Institute of Allergy and Infectious Diseases, Office of the \\ Director of Intramural Research Programs, Bethesda, MD 20205, USA
}

(Received 20 October 1986)

\begin{abstract}
The susceptibility of inbred strains of mice to infection by phase I Coxiella burnetii, the aetiological agent of $\mathrm{Q}$ fever, was investigated by evaluating morbidity, mortality, antibody production and in vitro proliferative responses of splenic lymphocytes. Among the 47 strains of mice tested for morbidity and mortality to C. burnetii infection, 33 were resistant, 10 were of intermediate sensitivity, and four were sensitive. A/J mice exhibited the highest mortality, and surviving mice of this strain yielded high concentrations of viable rickettsiae from essentially all organs for more than 3 weeks after inoculation. However, $\mathrm{A} / \mathrm{J}$ mice developed a protective immune response after vaccination with inactivated $C$. burnetii cells. Induction of gross pathological responses and antibody production were similar in sensitive mice (strain $\mathrm{A} / \mathrm{J}$ ) and resistant mice (strain $\mathrm{C} 57 \mathrm{BL} / 6 \mathrm{~J}$ ). The $\mathrm{LD}_{50}$ of phase I C. burnetii for $\mathrm{A} / \mathrm{J}$ mice was about 1000 fold lower than that for the more resistant $\mathrm{C} 57 \mathrm{BL} / 6 \mathrm{~J}$ mice. Mice of both strains developed antibody titres against phase I cells, phase II cells, and phase I lipopolysaccharide after the injection of one or more viable phase I organisms of $C$. burnetii; five or more rickettsiae caused splenomegaly that was almost proportional to the infecting dose. Suppression of in vitro proliferative responses of splenic lymphocytes to concanavalin A, a T-cell mitogen, was apparent after infection of sensitive $\mathbf{A} / \mathbf{J}$ mice with as few as one to five phase I micro-organisms. However, suppression of proliferation of splenic lymphocytes from resistant $\mathrm{C} 57 \mathrm{BL} / 6 \mathrm{~J}$ mice required $10^{7}$ phase I C. burnetii.
\end{abstract}

\section{INTRODUCTION}

The quest for an immunologically unaltered animal that exhibits the spectrum of pathogenetic reactions caused by Coxiella burnetii, the aetiological agent of $\mathrm{Q}$ fever, with a concomitant significant mortality rate, was the subject of the current study. Hosts involved in the epizootiology of $Q$ fever range from animal ectoparasites to man (Ormsbee, 1965). A microorganism adapted to growth in so many species has probably evolved a strategy of peaceful coexistence (Hackstadt \& Williams, 1981). Since the discovery of Q fever (Derrick, 1937) extensive studies on the infectivity of $C$. burnetii for various animals have been undertaken. Although one micro-organism is sufficient to cause $Q$ fever in small laboratory animals used for experimental purposes, pathogenic reactions depend on the virulence of the strain and the dose inoculated (Hackstadt \& Williams, 1981; Ormsbee et al., 1978). Mice and guinea pigs are used routinely as experimental animals for pathogenesis and immunogenesis studies with phase I $C$. burnetii (Ormsbee, 1965; Paretsky et al., 1964). Although both species are highly susceptible,

\footnotetext{
Abbreviations: Con A, concanavalin A; IFA, indirect fluorescent antibody; i.p., intraperitoneally; LPS-I, phase I lipopolysaccharide.
} 
infected animals rarely demonstrate morbidity. Mortality occurs in mice only when large doses of viable or inactivated phase I C. burnetii are administered (Williams \& Cantrell, 1981).

The availability of inbred mice strains carrying resistance genes to a number of bacterial and viral infections has refined the experimental approaches for the development of small animal models for studying various infectious diseases (Cheers \& McKenzie, 1978; Lopez, 1975; Plant \& Glynn, 1976). Genes outside the $\mathrm{H}-2$ complex controlling susceptibility to various infectious diseases are thought to represent mechanisms other than those involving specific immune recognition (Groves et al., 1980; Skamene et al., 1979). Patterns of susceptibility among inbred and outbred strains of mice to lethal infections with Rickettsia tsutsugamushi are mouse-straindependent (Groves \& Osterman, 1978). Natural resistance to the Gilliam strain of $R$. tsutsugamushi is controlled by a single autosomal dominant gene unlinked to the H-2 complex (Groves et al., 1980). Susceptibility of inbred mouse strains to $R$. akari, the aetiological agent of rickettsial pox, was not easily correlated with a specific genotype, thus demonstrating a wide range of pathogenic responses in various mice. Among the strains surveyed, resistant strains survived a challenge dose of $10^{5}$ more rickettsiae than the lethal dose for sensitive strains (Anderson \& Osterman, 1980). Although $R$. akari is markedly different from C. burnetii, these studies suggest that selected inbred strains of mice might exhibit increased sensitivity to infections by phase I $C$. burnetii.

In the present study, inbred strains of mice were tested for morbidity and mortality after infection by phase I $C$. burnetii. The dissemination and replication of $C$. burnetii in the most sensitive strain $(A / J)$, and the ability of this strain to mount a protective immune response after vaccination were examined. The effects of $C$. burnetii infection in a resistant (C57BL/6J) and a sensitive $(A / J)$ strain were compared after administration of varying doses of phase I rickettsiae. Gross pathological responses, the production of antibodies against phase I and phase II whole cells and against the phase I lipopolysaccharide (LPS-I), and the modulation of in vitro proliferative responses of splenic lymphocytes from these representative strains were examined.

\section{METHODS}

Mice. Forty-seven strains of inbred female mice, 6-7 weeks old, were evaluated. Mice were purchased from the Jackson Laboratory, Bar Harbor, Maine, USA; Charles River Breeding Laboratories Inc., Wilmington, Mass., USA; and the Division of Research Services, National Institutes of Health, Bethesda, Md., USA. Prior to use samples of mice from each shipment were examined for histopathological lesions, and tested serologically for 10 common mouse pathogens including lymphocytic choriomeningitis, sendai and mouse hepatitis virus. Mice were housed 10 per cage in a ventilated room at $23-24^{\circ} \mathrm{C}$. Commercial laboratory diet and water were provided ad libitum.

C. burnetii. The Nine Mile isolate of C. burnetii in phase I (fourth egg passage) was prepared as a $50 \%(\mathrm{w} / \mathrm{v})$ yolksac suspension in brain heart infusion broth (BHI), shell-frozen, and stored at $-70^{\circ} \mathrm{C}$.

Evaluation of sensitive and resistant strains. Groups of 10 mice from each strain were inoculated intraperitoneally (i.p.) with $10^{6.5}$ rickettsiae contained in $0.2 \mathrm{ml} \mathrm{BHI}$. Mice were observed daily for morbidity (visually expressed as roughened fur, lethargy, weakness, huddling) and mortality during a $28 \mathrm{~d}$ post-injection period. Mice that survived for $28 \mathrm{~d}$ were exsanguinated and their sera were pooled by groups for the determination of anti-C. burnetii antibodies. Strains of mice that exhibited neither overt signs of morbidity nor mortality were classified resistant. Strains in which the inoculated mice became moribund, but suffered no mortalities, were classified as being of intermediate sensitivity to infection, and strains in which mortalities occurred were considered sensitive.

Vaccine. Formalin-inactivated, phase I whole-cell vaccine was prepared initially for human use from the Henzerling strain of $C$. burnetii by Merrell-National Laboratories, Swiftwater, Pa., USA, and designated NDBR 105. Procedures for the growth of the $C$. burnetii in yolk-sacs of embryonated chicken eggs, inactivation with formalin, and purification were as previously described (Spicer \& DeSanctis, 1976). Purified C. burnetii were suspended $\left(1 \mathrm{mg} \mathrm{ml}{ }^{-1}\right)$ in phosphate-buffered saline (PBS; $0.15 \mathrm{M}$-sodium chloride, $0 \cdot 15 \mathrm{M}$-sodium phosphate, pH 7.0) containing $0.01 \%(\mathrm{w} / \mathrm{v})$ merthiolate, diluted to $120 \mu \mathrm{g}$ micro-organisms (dry wt) $\mathrm{ml}^{-1}$ with $4 \%$ (w/v) lactose, and freeze-dried. The vaccine was reconstituted in sterile physiological saline $(0.85 \%, w / v)$ for injection.

Antibody measurements. Sera from mice given injections of either viable phase I or killed $C$. burnetii vaccine were tested for antibody against phase II $C$. burnetii by the indirect fluorescent antibody (IFA) method (Philip \& Casper, 1978). Antibodies against phase I and phase II whole cells and LPS-I were quantified by ELISA (Williams et al., 1986). Titres were expressed as the reciprocals of the highest serum dilution that gave a positive reaction.

Titration of rickettsiae in infected tissues. Tissues were prepared as $10 \%(\mathrm{w} / \mathrm{v}) \mathrm{BHI}$ homogenates. Groups of seven 


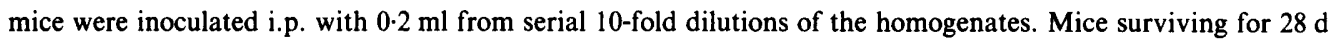
were exsanguinated and the individual sera were tested for antibodies to $C$. burnetii. Mice that died or seroconverted were considered infected and the median infective dose ( MID $_{50}$ ) for each sample was calculated using the moving average method (Thompson, 1947). One C. burnetii organism is required to establish infection in mice (Ormsbee et al., 1978).

Lymphocyte proliferation assays. At various times after infection, mice were bled from the orbital venous plexus, then killed by cervical dislocation. Spleens were aseptically removed and weighed, and organs were inspected for signs of gross necrotic foci. After the spleen weights had been determined, single-cell suspensions of spleens from control and test mice were prepared by gentle disruption through a wire screen into ice-cold RPMI 1640 medium (Moore et al., 1967) containing $5 \%(\mathrm{v} / \mathrm{v})$ heat-inactivated foetal calf serum, $50 \mu \mathrm{M}-2$-mercaptoethanol, and $50 \mu \mathrm{g}$ gentamicin sulphate $\mathrm{ml}^{-1}$. Spleen cells were washed twice in cold RPMI medium and adjusted to a concentration of $2 \times 10^{6}$ nucleated cells $\mathrm{ml}^{-1}$. Lymphocyte proliferation assays were done using a microculture assay procedure described by Damrow et al. (1985). Cultures were stimulated in vitro with either concanavalin A (Con A) at $1.0 \mu \mathrm{g} \mathrm{ml}^{-1}$, or with killed whole cells of phase I C. burnetii as recall antigen at $5 \mu \mathrm{g}(\mathrm{dry} \mathrm{wt}) \mathrm{ml}^{-1}$. The proliferative responses of lymphocytes were expressed as stimulation indices (SI) computed as follows:

$$
\mathrm{SI}=\frac{\text { c.p.m. (mitogen- or antigen-stimulated) }}{\text { c.p.m. (unstimulated controls) }}
$$

\section{RESULTS}

\section{Infection of mice with $C$. burnetii}

Observation of morbidity and mortality in inbred strains of mice after i.p. injection of $C$. burnetii indicated that mice in 14 of the 47 strains tested became overtly ill (Table 1). The majority $(90-100 \%)$ of mice in substrains of the A, BALB, and 129 lines became ill within 3-6 d of inoculation and the average duration of illness was 3-17 d. Comparison of the strains based on the numbers ill and duration of illness showed no correlation with major histocompatibility complex (MHC) genes. Mortalities were observed in the $\mathrm{H}-2^{\mathrm{a}}, \mathrm{H}-2^{\mathrm{q}}$ and $\mathrm{H}-2^{\mathrm{d}}$ haplotypes, but other strains with the same haplotypes were resistant. Although the incidence of mortality

Table 1. Responses of inbred strains of mice to i.p. inoculation with $10^{6 \cdot 5}$ phase I C. burnetii, Nine Mile isolate

Ten of each mouse strain were inoculated. Observations were terminated after $28 \mathrm{~d}$.

\begin{tabular}{|c|c|c|c|c|c|}
\hline \multirow[b]{2}{*}{ Mouse strain } & \multirow[b]{2}{*}{$\begin{array}{c}\mathbf{H}-2 \\
\text { haplotype }\end{array}$} & \multicolumn{2}{|c|}{ Overt illness* } & \multirow[b]{2}{*}{$\begin{array}{c}\text { No. mice } \\
\text { dead } / \\
\text { total }\end{array}$} & \multirow[b]{2}{*}{$\begin{array}{c}\text { IFA } \\
\text { titre† }\end{array}$} \\
\hline & & $\begin{array}{l}\text { Percentage } \\
\text { of mice } \\
\text { affected }\end{array}$ & $\begin{array}{l}\text { Mean } \\
\text { duration } \\
\text { (d) }\end{array}$ & & \\
\hline $\mathbf{A} / \mathbf{J}$ & $\mathbf{a}$ & 100 & $4 \cdot 0$ & $7 / 10$ & 1280 \\
\hline $\mathrm{A} / \mathrm{HeJ}$ & a & 100 & 3.5 & $0 / 10$ & 640 \\
\hline A/WySnJ & a & 90 & 6.5 & $3 / 10$ & 1280 \\
\hline $\mathrm{AU} / \mathrm{SsJ}$ & $q$ & 40 & 7.8 & $3 / 10$ & 640 \\
\hline BALB/cByJ & $\mathrm{d}$ & 90 & $10 \cdot 4$ & $0 / 10$ & 1280 \\
\hline BALB/cDub & - & 100 & $4 \cdot 2$ & $0 / 10$ & 1280 \\
\hline $\mathrm{BALB} / \mathrm{cJ}$ & $\mathrm{d}$ & 100 & 7.0 & $0 / 11$ & 1280 \\
\hline $\mathrm{BALB} / \mathrm{cNcrlBr}$ & - & 100 & 17.0 & $0 / 10$ & 2560 \\
\hline $\mathrm{BDP} / \mathrm{J}$ & $\mathrm{p}$ & 70 & 3.6 & $0 / 10$ & ND \\
\hline $\mathrm{C} 3 \mathrm{H} / \mathrm{HeJ}$ & $\mathrm{k}$ & 50 & $3 \cdot 1$ & $0 / 10$ & 640 \\
\hline $\mathrm{NZB} / \mathrm{BinJ}$ & d & 40 & $2 \cdot 6$ & $2 / 10$ & 640 \\
\hline LG $/ J$ & d & 20 & $3 \cdot 0$ & $0 / 10$ & 2560 \\
\hline $129 / \mathrm{SvJ}$ & b & 90 & 5.9 & $0 / 10$ & 2560 \\
\hline $129 / \mathrm{J}$ & b & 90 & $8 \cdot 3$ & $0 / 10$ & 1280 \\
\hline
\end{tabular}

ND, Not done.

-, Haplotype unknown.

* Mice with overt illness were lethargic and had rough fur.

$\dagger$ Pool of sera from survivors; reciprocal of highest positive dilution. 
Table 2. Inbred strains of mice that exhibited no overt signs of illness after i.p. injection of phase I C. burnetii

\begin{tabular}{|c|c|c|c|c|c|}
\hline $\begin{array}{l}\text { Mouse } \\
\text { strain }\end{array}$ & $\begin{array}{c}\mathrm{H}-2 \\
\text { haplo- } \\
\text { type }\end{array}$ & $\begin{array}{l}\text { IFA } \\
\text { titre* }\end{array}$ & $\begin{array}{l}\text { Mouse } \\
\text { strain }\end{array}$ & $\begin{array}{c}\mathrm{H}-2 \\
\text { haplo- } \\
\text { type }\end{array}$ & $\begin{array}{l}\text { IFA } \\
\text { titre* }\end{array}$ \\
\hline $\mathrm{AKR} / \mathrm{J}$ & k & 2560 & $\mathrm{C} 57 \mathrm{~L} / \mathrm{J}$ & b & 640 \\
\hline $\mathrm{CBA} / \mathrm{CaJ}$ & $\mathrm{k}$ & 1280 & C57/6FMaiBR & - & 1280 \\
\hline $\mathrm{CBA} / \mathrm{J}$ & $\mathrm{k}$ & 2560 & $\mathrm{C} 58 / \mathrm{J}$ & $\mathrm{k}$ & 1280 \\
\hline CBA/HT6J & $\mathrm{k}$ & 2560 & $\mathrm{DBA} / \mathbf{I J}$ & $q$ & 1280 \\
\hline $\mathrm{CE} / \mathrm{J}$ & $\mathrm{k}$ & ND & $\mathrm{DBA} / 2 \mathrm{~J}$ & $\mathrm{~d}$ & 2560 \\
\hline $\mathrm{C} 3 \mathrm{H} / \mathrm{HeN}$ & $\mathrm{k}$ & 1280 & $\mathrm{DBA} / 2 \mathrm{FMaiBR}$ & - & 1280 \\
\hline $\mathrm{C} 3 \mathrm{H} / \mathrm{HeSnJ}$ & $\mathrm{k}$ & 1280 & $\mathrm{I} / \mathrm{LnJ}$ & $\mathrm{j}$ & 1280 \\
\hline $\mathrm{C} 3 \mathrm{H} / \mathrm{Rv}$ & - & 1280 & MA/MyJ & $\mathrm{k}$ & 1280 \\
\hline $\mathrm{C} 3 \mathrm{H} / \mathrm{HeDub}$ & k & 640 & $\mathrm{PL} / \mathrm{J}$ & u & ND \\
\hline C3H/BiMaiBR & - & 640 & $\mathrm{RF} / \mathrm{J}$ & k & 2560 \\
\hline $\mathrm{CeHeB} / \mathrm{FeJ}$ & k & 2560 & RIIS/J & $\mathrm{r}$ & 1280 \\
\hline $\mathrm{C} 57 \mathrm{BL} / \mathrm{KSJ}$ & d & 1280 & $\mathrm{SEA} / \mathrm{GnJ}$ & d & ND \\
\hline $\mathrm{C} 57 \mathrm{BL} / 6 \mathrm{~J}$ & b & 2560 & SEC/ReJ & d & 1280 \\
\hline $\mathrm{C} 57 \mathrm{BL} / 10 \mathrm{~J}$ & b & 2560 & $\mathrm{SJL} / \mathrm{J}$ & $\mathrm{s}$ & 2560 \\
\hline C57BL/10SnJ & b & 1260 & $\mathrm{ST} / \mathrm{bJ}$ & $\mathrm{k}$ & 2560 \\
\hline C57BL/6ByJ & b & 2560 & $\mathrm{SWR} / \mathrm{J}$ & q & 1280 \\
\hline $\mathrm{C} 57 \mathrm{BR} / \mathrm{cdJ}$ & k & 320 & & & \\
\hline
\end{tabular}

varied in separate experiments, the highest incidence consistently occurred in $\mathrm{A} / \mathrm{J}$ mice. Quality assurance testing on the mouse populations indicated that this variation could not be attributed to adventitious agents.

Thirty-three strains without overt signs of illness after infection were classified as resistant (Table 2). Although antibody titres in resistant strains were higher than would be expected without replication of the injected organisms, these mice remained healthy and vigorous throughout the $28 \mathrm{~d}$ observation period. Antibody titres in surviving mice from the various strains ranged from 320 to 2560 . There were no consistent differences among antibody titres in strains with inapparent infections and titres in those that became ill. No correlation was observed between antibody titre and $\mathrm{H}-2$ haplotype.

After infection of the sensitive $\mathrm{A} / \mathrm{J}$ mice $C$. burnetii were detected in every organ examined. Viable $C$. burnetii in various tissues were titrated at intervals from 4 to $21 \mathrm{~d}$ after the mice were inoculated. Blood samples taken $4 \mathrm{~d}$ after inoculation contained more than $10^{3 \cdot 4}$ C. burnetii $\mathrm{ml}^{-1}$ and even higher titres $\left(>10^{5}\right)$ were present in other tissues. The following peak concentrations (number of micro-organisms per $\mathrm{ml}$ or per $\mathrm{g}$ of tissue) occurred $7 \mathrm{~d}$ after inoculation: whole blood, $10^{4 \cdot 2}$; heart, $10^{7 \cdot 3}$; liver, $10^{7 \cdot 5}$; lung, $10^{7 \cdot 3}$; spleen, $10^{6 \cdot 8}$; kidney, $10^{7 \cdot 9}$; brain, $10^{5 \cdot 7}$. Estimates of the tissue burdens were of course somewhat confounded by the presence of $C$. burnetii in whole blood. However, after $7 \mathrm{~d}$ the numbers of viable $C$. burnetii in all organs began to decrease. Concentrations ranging from $10^{2 \cdot 7}(\mathrm{~g} \text { brain })^{-1}$ to $10^{5 \cdot 7}$ ( $\mathrm{g}$ spleen $)^{-1}$ were present 3 weeks after the mice were infected.

\section{Protective immune response in vaccinated $A / J$ mice}

Since $\mathrm{A} / \mathrm{J}$ mice were the most sensitive of the strains examined, the ability of this strain to develop a protective immune response against virulent $C$. burnetii challenges was determined. Three groups of mice were given a single $0.2 \mathrm{ml}$ subcutaneous injection that contained either $0 \cdot 25,2.5$ or $25.0 \mu \mathrm{g}$ vaccine. Animals in a fourth group received two subcutaneous injections each containing $12.5 \mu \mathrm{g}$ vaccine at a $7 \mathrm{~d}$ interval. Control mice were injected twice with saline. Eight weeks after injection, mice from each group were challenged i.p. with $10^{7}$ phase I $C$. burnetii, Nine Mile strain. 
Table 3. Antibody titres in the sera of $A / J$ mice injected with inactivated phase I C. burnetii vaccine

Time of titration (weeks postvaccination)

\begin{tabular}{|c|c|c|c|c|}
\hline \multirow{2}{*}{$\begin{array}{l}\text { Vaccine } \\
\text { dose }(\mu \mathrm{g})\end{array}$} & \multicolumn{4}{|c|}{ IFA titre* } \\
\hline & $25 \dagger$ & 25 & 2.5 & 0.25 \\
\hline & $\begin{array}{l}106 \pm 27 \\
213 \pm 53 \\
640 \pm 0\end{array}$ & $\begin{array}{l}426 \pm 106 \\
160 \pm 0 \\
133 \pm 27\end{array}$ & $\begin{array}{l}67 \pm 13 \\
67 \pm 13 \\
13 \pm 3\end{array}$ & $\begin{array}{r}13 \pm 3 \\
<10 \pm 0 \\
<10 \pm 0\end{array}$ \\
\hline
\end{tabular}

* Mean \pm standard error of titres from three mice.

$\dagger$ Given in two equal subcutaneous injections, $7 \mathrm{~d}$ apart. All other doses were given as a single injection.

Table 4. Effect of vaccination on the resistance of $A / J$ mice to $C$. burnetii infection

A dose of $10^{7} \mathrm{MID}_{50}$ phase I C. burnetii was injected i.p. 8 weeks after vaccination.

$\begin{array}{cccr}\begin{array}{c}\text { Vaccine dose } \\ (\mu \mathrm{g})\end{array} & \text { IFA titre* } & \overbrace{\text { With overt illness }}^{\text {No. of mice responding/total }} & \text { Dead } \\ \text { None } & 0 & 57 / 57 & 23 / 57 \\ 0.25 & <10 \pm 0 & 3 / 26 & 2 / 26 \\ 2.5 & 13 \pm 3 & 0 / 27 & 0 / 27 \\ 25 & 133 \pm 27 & 0 / 27 & 0 / 27 \\ 25 \dagger & 640 \pm 0 & 0 / 30 & 0 / 30\end{array}$

* Mean \pm standard error of titres from three mice.

$\dagger$ Given as two equal subcutaneous injections, $7 \mathrm{~d}$ apart. All other doses were given as a single injection.

Antibody titres elicited in vaccinated mice were related to the amount of vaccine injected and whether it was administered in a single or divided dose (Table 3). Administering the vaccine in two separate injections given $7 \mathrm{~d}$ apart elicited higher and more stable titres than the same amount given as a single dose. Titres in mice that received the divided vaccine dose were still at peak levels after 2 months, while titres in mice that received the same amount of antigen in a single injection started to decline within 4 weeks. A dose of $0.25 \mu \mathrm{g}$ vaccine stimulated minimal antibody titres after 2 weeks, but antibody was not detected thereafter. However, only 3 of 26 low-dose vaccinated mice became ill after challenge with virulent rickettsiae. In contrast, $100 \%$ morbidity and $40 \%$ mortality were observed among the non-vaccinated control mice (Table 4). Mice receiving $2.5 \mu \mathrm{g}$ or more of the vaccine either as single or as a divided dose, did not become ill, and no deaths were observed after challenge.

\section{Lethality and splenomegaly in resistant and sensitive strains}

Groups of resistant $\mathrm{C} 57 \mathrm{BL} / 6 \mathrm{~J}$ and sensitive $\mathrm{A} / \mathrm{J}$ mice were injected with mean doses ranging from $10^{-1 \cdot 3}$ to $10^{10 \cdot 7}$ infectious Nine Mile strain phase I C. burnetii. All A/J mice that received $10^{7 \cdot 7}$ or more Coxiella died, with a mean survival time of $8 \mathrm{~d}$ or less (Table 5). No deaths resulted from lower doses. In contrast, $\mathrm{C} 57 \mathrm{BL} / 6 \mathrm{~J}$ mice did not succumb to doses below $10^{8 \cdot 7}$ microorganisms, and doses of $10^{10 \cdot 7}$ were required to kill $89 \%$ of the mice. The $\mathrm{LD}_{50}$ of the $\mathrm{A} / \mathrm{J}$ mice $\left(10^{7 \cdot 1}\right)$ was about 1000 -fold lower than for the more resistant C57BL/6J mice $\left(10^{9 \cdot 9}\right)$.

Significant $(P<0.05)$ increases in spleen mass were observed in surviving mice of both strains $30 \mathrm{~d}$ after being inoculated with five or more viable rickettsiae. The degree of splenomegaly was roughly proportional to the dose received by both strains. Pathological lesions, visible as necrotic foci in the liver, were evident in $50 \%$ of the surviving C $57 \mathrm{BL} / 6 \mathrm{~J}$ mice that were injected with $10^{8.7}$ or more rickettsiae. All of the $\mathrm{A} / \mathrm{J}$ mice that were injected with $10^{7 \cdot 7}$ or more organisms died and were not examined for necrotic lesions. Lesions were not observed in surviving $\mathrm{A} / \mathrm{J}$ mice that were injected with lower doses of $C$. burnetii. 


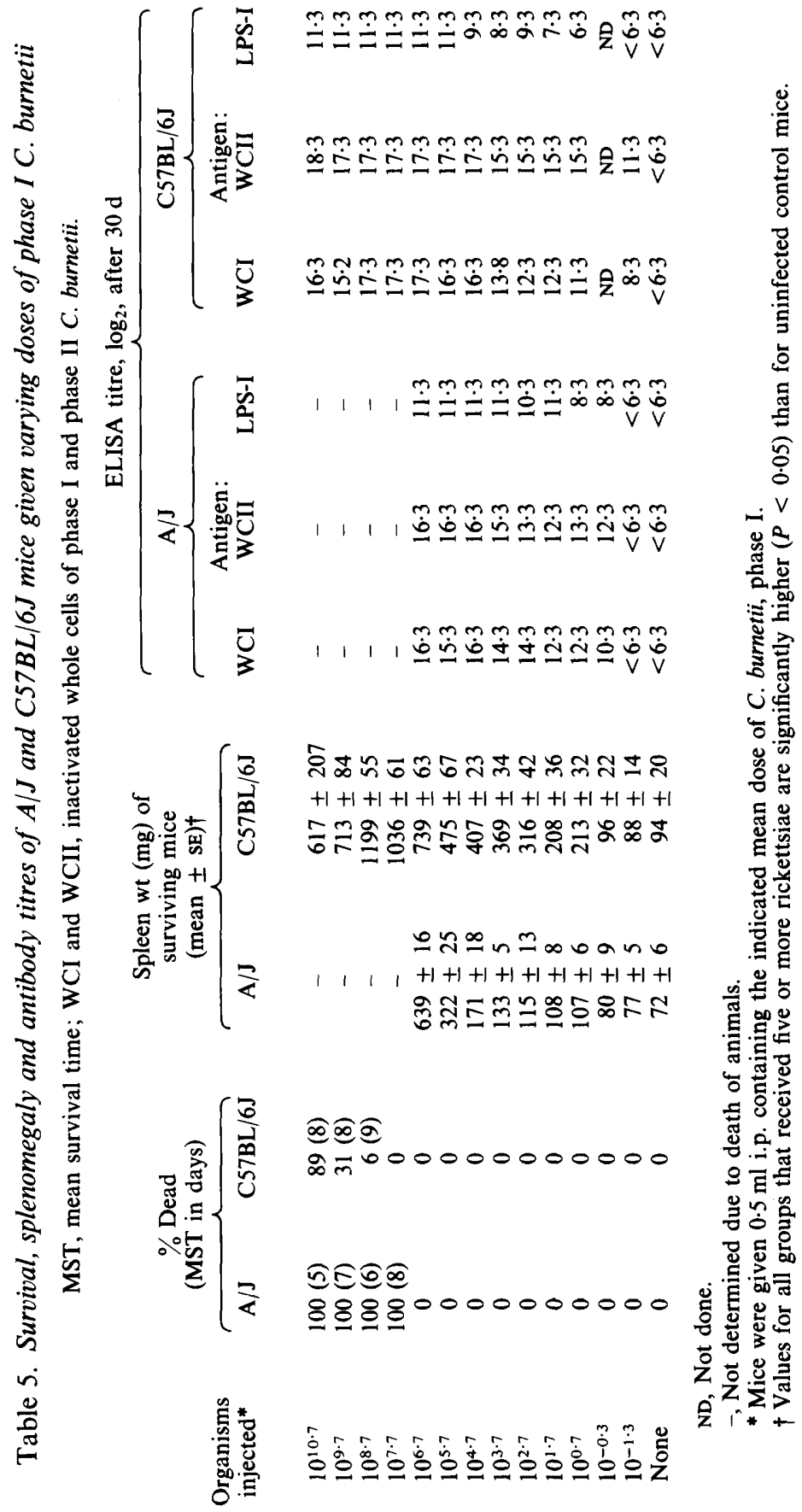



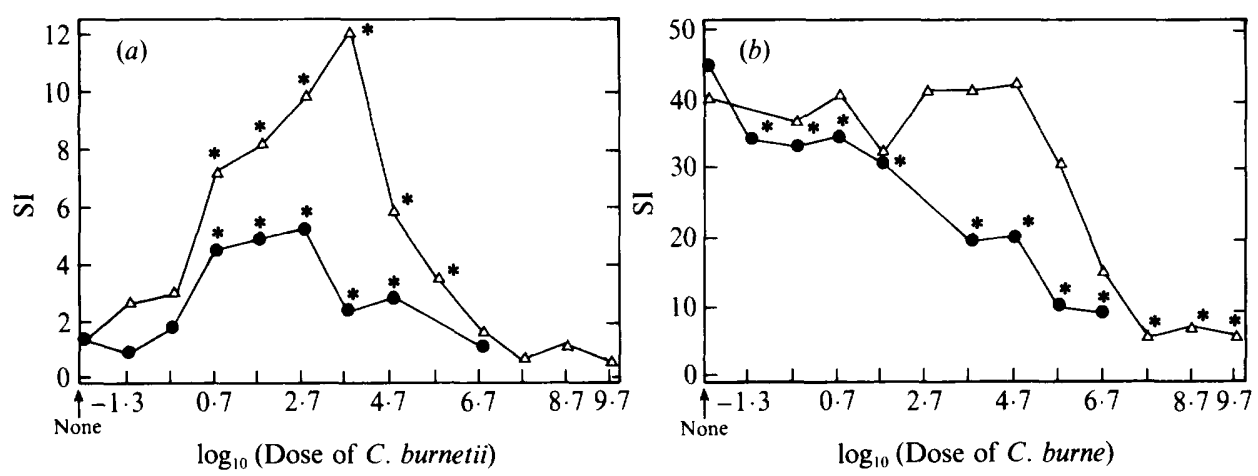

Fig. 1. In vitro responses of spleen cells from $\mathrm{A} / \mathrm{J}(\bigcirc)$ and $\mathrm{C} 57 \mathrm{BL} / 6 \mathrm{~J}(\triangle)$ mice to inactivated whole cells of phase I $C$. burnetii $(a)$, and to Con A $(b)$ after varying doses of phase I C. burnetii. Mice were given an i.p. injection containing the indicated concentrations of $C$. burnetii $30 \mathrm{~d}$ prior to the assay.*, Significantly different from the stimulation index (SI) of cells from uninfected mice $(P<0.05 \%)$.

\section{Immune response in $\mathrm{A} / \mathrm{J}$ and $\mathrm{C} 57 \mathrm{BL} / 6 \mathrm{~J}$ mice}

Previous studies, which centred around the cellular immune responses of $\mathrm{C} 57 \mathrm{BL} / 10 \mathrm{ScN}$ mice either vaccinated or infected with phase I C. burnetii, indicated that pathogenic reactions were expressed as mitogenic hyporesponsiveness and antigenic negative modulation of splenic lymphocytes (Williams \& Cantrell, 1981; Damrow et al., 1985). Modulation of antibody production against phase I and phase II whole cells was not demonstrated. In the current study, we tested the in vitro proliferative responses of splenic lymphocytes and the production of specific antibodies against phase I cells, phase II cells and phase I-LPS antigens $30 \mathrm{~d}$ after infection of $\mathrm{A} / \mathrm{J}$ and $\mathrm{C} 57 \mathrm{BL} / 6 \mathrm{~J}$ mice with graded doses of phase $\mathrm{I} C$. burnetii.

Mice of both strains that received at least one viable micro-organism developed antibody titres against phase I, phase II, and LPS antigens. Equivalent but dose-dependent titres were obtained in both strains of mice; the highest titres developed in mice that were injected with the greatest number of organisms. However, the proliferative responses of splenic lymphocytes from infected $\mathrm{C} 57 \mathrm{BL} / 6 \mathrm{~J}$ mice to recall antigen were significantly higher $(P<0.05)$ than those from $\mathrm{A} / \mathrm{J}$ mice for all doses up to $10^{5 \cdot 7}$ micro-organisms (Fig. 1). Stimulation indices of splenic lymphocytes from $\mathrm{C} 57 \mathrm{BL} / 6 \mathrm{~J}$ mice increased concomitantly with dose and were maximal in mice injected with $10^{3 \cdot 7}$ organisms. Stimulation responses declined with further increases in the infecting dose; thus the proliferative response of splenic lymphocytes from C57BL/6J mice injected with $10^{6.7}$ or more rickettsiae were no higher than those of cells from uninfected mice.

Infection with low doses of $C$. burnetii also enhanced the proliferative responses of splenic lymphocytes from $\mathrm{A} / \mathrm{J}$ mice to recall antigen. However, the peak response of this sensitive strain was inferior to that observed in the resistant strain, and was diminished in mice injected with more than $10^{2 \cdot 7}$ rickettsiae.

Although enhanced responsiveness to recall antigen was observed after moderate infective doses of rickettsia, the Con A stimulated response of splenic lymphocytes from $\mathrm{A} / \mathrm{J}$ mice injected with only one micro-organism was significantly $(P<0.05 \%)$ suppressed below that of cells from uninfected mice. The magnitude of suppression was greater with increasing doses. By contrast, the mitogenic response of splenic lymphocytes from the resistant mouse strain was not affected by low to moderate infective doses, and was not suppressed significantly unless more than $10^{6 \cdot 7}$ C. burnetii were injected.

\section{DISCUSSION}

In this study some differences in susceptibility and resistance among inbred strains of mice to infection by $C$. burnetii were determined. In terms of overt illness and mortality, $\mathrm{A} / \mathrm{J}$ mice were the most sensitive of 47 strains surveyed. $\mathrm{C} 57 \mathrm{BL} / 6 \mathrm{~J}$ mice were 1000 -fold more resistant to lethal 
infection than the sensitive $\mathrm{A} / \mathrm{J}$ strain. A minimum dose containing $10^{7 \cdot 7}$ C. burnetii was required to achieve $100 \%$ mortality in $\mathrm{A} / \mathrm{J}$ mice; few deaths occurred in mice injected with less than $10^{6.5}$ micro-organisms. Death could not be assigned to the infection of any individual organ because $C$. burnetii were disseminated to essentially all vital organs. In eight of the strains surveyed, the infection only caused overt illness in $70-100 \%$ of the inoculated mice; these included four BALB/c strains, two 129 strains, the $\mathrm{A} / \mathrm{HeJ}$ strain and the $\mathrm{BDP} / \mathrm{J}$ strain. Mice in these moderately susceptible strains exhibited roughened fur and lethargy for periods of up to $17 \mathrm{~d}$, and in all instances, infected mice were easily distinguished from sham-inoculated mice. As anticipated, the infection was inapparent in most of the resistant strains tested.

Comparison of known $\mathrm{H}-2$ haplotypes of the strains tested according to their relative sensitivities to $Q$ fever revealed that one $(A / H e J)$ of the three $\mathrm{H}-2^{2}$ strains was moderately sensitive and that two strains (A/J and $\mathrm{A} / \mathrm{WySnJ}$ ) were sensitive. All but one of $15 \mathrm{H}-2^{\mathrm{k}}$ strains were resistant. No other correlation between $\mathrm{H}-2$ haplotype and sensitivity to $C$. burnetii was evident. The fact that the $\mathrm{H}-2^{\mathrm{a}}$ strains were susceptible suggests that this locus, or the A background, or both, influence immunological interactions. Before a function to the $\mathrm{H}-2^{\mathrm{a}}$ haplotype is assigned, genetic analyses of other factors which influence susceptibility must be considered. The A/J mouse is a low interferon producer (If-1'), and it has deficiencies in the complement pathway $\left(\mathrm{Hc}, \mathrm{C5a}^{-}\right)$(Cerquetti et al., 1983; Gervais et al., 1984; Koster et al., $1985 \mathrm{a}$ ) and in macrophage (Mac) functions (Boraschi \& Meltzer, 1979). Defects in macrophageactivating capacity play a role in the susceptibility of mice to other rickettsiae. However, the defect in macrophage function is not due to allelic differences at the lipopolysaccharide locus. Accumulation of deficiencies is probably responsible for the susceptibility of the $\mathrm{A} / \mathrm{J}\left(\mathrm{C}^{-} \mathrm{a}^{-}\right.$, If $\left.-1^{1}, \mathrm{Mac}^{-}\right)$and the resistance of DBA/2J $\left(\mathrm{C}^{-} \mathrm{a}^{-}, \mathrm{If}^{-} \mathrm{1}^{\mathrm{h}}, \mathrm{Mac}^{+}\right)$to $\mathrm{Q}$ fever. Although both strains of mice are deficient in secretion of $\mathrm{C} 5$, differences in interferon production and macrophage function may be determining factors in resistance. Gamma interferon inhibits the growth of $C$. burnetii in cultured mouse fibroblasts (Turco et al., 1984). Therefore, the effects of C5, of interferon, and of macrophage function deficiencies on the susceptibility of $\mathrm{A} / \mathrm{J}$ mice to $C$. burnetii require thorough study.

Examination of other genetic loci and inherent alleles for the 47 mouse strains identified a statistical correlation between the Ighle allele and sensitivity. Interestingly, the sensitive $\mathrm{A} / \mathrm{J}$ strain is the prototype strain for the Ighle allele. The cellular immunological mechanisms of the Ighle $^{\mathbf{e}}$ allele may be significant in $\mathrm{Q}$ fever.

Antibody to $\mathrm{Q}$ fever is thought to be detrimental to the host because it facilitates uptake and placement of $C$. burnetii in the phagolysosome, thereby facilitating the infection and spread of the agent in a sensitive host (Baca et al., 1984). In our experiments, both sensitive and resistant strains developed similar levels of anti-C. burnetii antibody after infection with only one microorganism, yet the progression of the infection in the respective strains was apparently quite different. Thus, it appears that the quantity of anti- $C$. burnetii antibody may not be a primary factor in the clearance of $C$. burnetii from either resistant or sensitive strains.

Since cell-mediated immune responses under genetic control are important in the clearance of intracellular parasites (Rosenstreich et al., 1982), we studied the in vitro proliferative responses of splenic lymphocytes from resistant $(\mathrm{C} 57 \mathrm{BL} / 6 \mathrm{~J})$ and sensitive $(\mathrm{A} / \mathrm{J})$ mouse strains to $C$. burnetii infections. Activated T-cells enhance the microbicidal activity of macrophages against $C$. burnetii and appear to play an important role in clearance (Kishimoto et al., 1978). Our studies clearly demonstrated that low levels of $C$. burnetii infection in the sensitive $\mathrm{A} / \mathrm{J}$ strain stimulated the specific in vitro proliferative response of splenic lymphocytes to recall antigen. In contrast, the specific response of $\mathrm{A} / \mathrm{J}$ splenic lymphocytes to the T-cell mitogen Con $\mathrm{A}$ was suppressed, even at minimal infection levels. However, the proliferative response to recall antigens of spleen cells from resistant $\mathrm{C} 57 \mathrm{BL} / 6 \mathrm{~J}$ mice were enhanced over widely varying doses of $C$. burnetii and much higher dosages $\left(10^{6}-10^{7}\right.$-fold) were tolerated without significant suppression of Con $\mathrm{A}$ response. Results of the lymphocyte proliferation assay to measure differences between sensitive and resistant strains suggest that the regulation of T-cell response is an important parameter in $\mathrm{Q}$ fever. Previous studies with mice and humans have correlated T-cell unresponsiveness with $\mathrm{Q}$ fever (Damrow et al., 1985; Koster et al., 1985a, b). 
The A/J strain, with its genetic defects, is currently the best mouse model for testing the efficacy of $\mathrm{Q}$ fever vaccines. We have demonstrated the sensitivity of $\mathrm{A} / \mathrm{J}$ mice to $C$. burnetii infection, and the ability of these mice to mount a protective immune response when vaccinated. Apparently the immunological factors which render the A/J strain sensitive were overcome by prior experience with appropriate immunogens of $C$. burnetii. The ability of sensitive mice to generate a protective immune response against lethal challenge offers a viable alternative to using the more cumbersome and expensive guinea pig model for testing candidate vaccines. Correction of immunological defects of the $\mathrm{A} / \mathrm{J}$ strain as congenic constructs should provide additional clues to the importance of the If -1 , the Ighle, and the Mac markers for sensitivity to $Q$ fever.

We thank D. M. Waag and M. J. England for technical assistance, and R. H. Kenyon and S. L. Welkos for review of the manuscript.

In conducting the research described in this report, the investigators adhered to the 'Guide for the Care and Use of Laboratory Animals', as promulgated by the Committee on Care and Use of Laboratory Animals of the Institute of Laboratory Animal Resources, National Research Council. The facilities are fully accredited by the American Association for Accreditation of Laboratory Animal Care.

\section{REFERENCES}

ANDERSon, G. W., JR \& Osterman, J. V. (1980). Host defense in experimental rickettsial pox: genetics of natural resistance to infection. Infection and Immunity 28, 132-136.

BaCa, O. G., Akporiaye, E. T. \& Rowatt, J. D. (1984). Possible biochemical adaptations of Coxiella burnetii for survival within phagocytes: effect of antibody. In Microbiology - 1984, pp. 269-272. Edited by L. Leive \& D. Schlessinger. Washington, DC: American Society for Microbiology.

Boraschi, D. \& Meltzer, M. S. (1979). Defective tumoricidal capacity of macrophages from $\mathrm{A} / \mathrm{J}$ mice. II. Comparison of the macrophage cytotoxic defect of $\mathrm{A} / \mathrm{J}$ mice with that of lipid A-unresponsive $\mathrm{C} 3 \mathrm{H} / \mathrm{HeJ}$ mice. Journal of Immunology 122, 1592 1597.

Cerquetti, M. C., Sordelli, D. O., Ortegon, R. A. \& Bellanti, J. A. (1983). Impaired lung defenses against Staphylococcus aureus in mice with hereditary deficiency of the fifth component of complement. Infection and Immunity 41, 1072-1076.

Cheers, C. \& MCKenzIE, I. F. C. (1978). Resistance and susceptibility of mice to bacterial infection: genetics of listeriosis. Infection and Immunity 19, 755 762.

Damrow, T. A., Williams, J. C. \& WaAg, D. M. (1985). Suppression of in vitro lymphocyte proliferation in $\mathrm{C} 57 \mathrm{BL} / 10 \mathrm{ScN}$ mice vaccinated with phase I Coxiella burnetii. Infection and Immunity 47, 149-156.

DERRICK, E. H. (1937). 'Q' fever, a new fever entity: clinical features, diagnosis, and laboratory investigations. Medical Journal of Australia 2, 281-299.

Gervais, F., Stevenson, M. \& Skamene, E. (1984). Genetic control of resistance to Listeria monocytogenes: regulation of leukocyte inflammatory responses by the Hc locus. Journal of Immunology 132, 2078-2083.

Groves, M. G. \& Osterman, J. V. (1978). Host defenses in experimental scrub typhus: genetics of natural resistance to infection. Infection and Immunity 19, 583-588.
Groves, M. G., Rosenstreich, D. L., Taylor, B. A. \& Osterman, J. V. (1980). Host defenses in experimental scrub typhus: mapping the gene that controls natural resistance in mice. Journal of Immunology 125, 1395-1399.

HaCkstadt, T. \& Williams, J. C. (1981). Biochemical stratagem for obligate parasitism of eukaryotic cells by Coxiella burnetii. Proceedings of the National Academy of Sciences of the United States of America 78, 3240-3244

Kishimoto, R. A., Johnson, J. W., Kenyon, R. H., Ascher, M. S., Larson, E. W. \& Pederson, C. E., JR (1978). Cell-mediated immune responses of guinea pigs to an inactivated phase I Coxiella burnetii vaccine. Infection and Immunity 19, 194-198.

Koster, F. T., Williams, J. C. \& Goodwin, J. S. $(1985 a)$. Cellular immunity in $Q$ fever: specific lymphocyte unresponsiveness in $\mathrm{Q}$ fever endocarditis. Journal of Infectious Diseases 152, 12831289.

Koster, F. T., Williams, J. C. \& Goodwin, J. S. $(1985 b)$. Cellular immunity in $\mathrm{Q}$ fever: modulation of responsiveness by a suppressor T-cell-monocyte circuit. Journal of Immunology 135, 1067-1072.

LOPEZ, C. (1975). Genetics of natural resistance to herpes virus infections in mice. Nature, London, 258, 152-155.

Moore, G. E., Gerner, R. F. \& Franklin, H. A. (1967). Culture of normal human leukocytes. Journal of the American Medical Association 199, 519-524.

ORMSBEE, R. A. (1965). Q fever rickettsiae. In Viral and Rickettsial Infections of Man, 4th edn, pp. 1144-1160. Edited by L. F. Horsfall \& I. Tamm. Philadelphia: Lippincott.

Ormsbee, R., Peacock, M., Gerloff, R., Tallent, G. \& WIKE, D. (1978). Limits of rickettsial infectivity. Infection and Immunity 19, 239-245.

Paretsky, D., Downs, C. M. \& Salman, C. W. (1964). Some biochemical changes in the guinea pig during infection with Coxiella burnetii. Journal of Bacteriology 88, 137-142. 
PhILIP, R. N. \& CASPER, E. A. (1978). Serotyping spotted fever-group rickettsiae with mouse antisera by microimmunofluorescence. A preliminary report. In Proceedings of the Second International Symposium on Rickettsiae and Rickettsial Diseases, pp. 307-311. Edited by J. Kazar, R. A. Ormsbee \& I. N. Tarasevich. Bratislava, Czechoslovakia: VEDA.

Plant, J. \& GlynN, A. A. (1976). Genetics of resistance to infection with Salmonella typhimurium in mice. Journal of Infectious Diseases 133, 72-78.

Rosenstreich, D. L., Weinblatt, A. C. \& O’Brien, A. D. (1982). Genetic control of resistance to infection in mice. CRC Critical Reviews in Immuno$\log y$ 3, 263-330.

Skamene, E., Kongshavn, P. A. L. \& Sachs, D. H. (1979). Resistance to Listeria monocytogenes in mice: genetic control by genes that are not linked to the H-2 complex. Journal of Infectious Diseases 139, 228-231.

Spicer, D. S. \& DeSanctis, A. N. (1976). Preparation of phase I Q fever antigen suitable for vaccine use. Applied and Environmental Microbiology 32, 85-88.

THOMPSON, W. R. (1947). Use of moving averages and interpolation to estimate median effective dose. I. Fundamental formulas, estimation of error, and relation to other methods. Bacteriological Reviews 11, 115-145.

TURCo, J., THOMPSON, H. A. \& WINKLER, H. H. (1984). Interferon- $\gamma$ inhibits growth of Coxiella burnetii in mouse fibroblasts. Infection and Immunity 45, 781783.

Williams, J. C. \& Cantrell, J. L. (1981). Biological and immunological properties of Coxiella burnetii vaccines in $\mathrm{C} 57 \mathrm{BL} / 10 \mathrm{ScN}$ endotoxin-nonresponder mice. Infection and Immunity 35, 1091-1102.

Williams, J. C., Thomas, L. A. \& Peacock, M. G. (1986). Identification of phase-specific antigenic fractions of Coxiella burnetii by enzyme-linked immunosorbent assay. Journal of Clinical Microbiology 24, 929-934. 